\title{
The meaning and dialectics of education, teaching, refinement, urbanisation and civilisation: a Khaldounic point of view
}

\author{
Jilani Ben Touhami Meftah \\ Department of Al-Quran and Al-Hadith, \\ Academy of Islamic Studies, \\ University Malaya, \\ 50603, Kuala Lumpur, Malaysia \\ E-mail: Babout2@yahoo.com
}

\begin{abstract}
This paper had attempted to highlight the meaning and dialectics of some of Ibn Khaldoun's very crux concepts: education teaching refinement, urbanisation and civilisation. It found that education is a natural process. It is somewhat similar to a contemporary concept of socialisation and its purpose - as the tool of socialisation - can be traced in the meaning of the word tarbiyah which means to educate, to cultivate, socialise and bring up people and things. Teaching is a natural phenomenon in human social organisation. As man by nature needs to eat, drink and have sexual requirement, he by nature needs learning and gaining knowledge, teaching itself is a craft, made perfect by habit (malakah). Refinement is to reach the level of good ethical refinement and leads to the development of a civilisation (hadarah) which is the diversification of luxuries, the cultivation of things, and the education to the crafts that give elegance to all the various kinds of luxuries. Thus is achieved through the human necessity to socialise and refine his crafts in various fields.
\end{abstract}

Keywords: education; teaching; refinement; urbanisation; civilisation; Ibn Khaldun.

Reference to this paper should be made as follows: Meftah, J.B.T. (2011) 'The meaning and dialectics of education, teaching, refinement, urbanisation and civilisation: a Khaldounic point of view', Int. J. Arab Culture, Management and Sustainable Development, Vol. 2, No. 1, pp.3-16.

Biographical notes: Jilani Ben Touhami Meftah is a Lecturer at the University of Malaya, Malaysia. He obtained his $\mathrm{PhD}$ in Education and Postgraduate Diploma in Human Sciences in Tafsir. He has several publications; main of them are his three books: The Arab Modernists and the Qur'anic Text (2005, University of Malaya Press, Malaysia); Al-Hadathiyun al-'Arab Fi al-'Uqud al-Thalathah al-'Akhirah wa al-Nas al-Qur'ani: Dirasah Naqdiyah (Dar al-Nahdah, Damascus, Syria) and Ibn Khaldoun's Philosophy of Man (An Educational Points of View) (2011, IIUM Press, Malaysia; Dar Al-Kotob Al-Ilmiyah, Beirut). 


\section{Introduction}

To many Western, Arab and Muslim scholars, Ibn Khaldun is considered the pioneer of social sciences. Hence, there are a huge number of books and articles in different languages, which have been written tackling Ibn Khaldun's ideas from the different perspectives of History, Sociology, Politics and Economics. In spite of their variety and importance, they seldom significantly exposed the dialectics of the very crux concepts in his thought. Therefore, the task of this paper is to highlight the meaning and dialectics of these concepts mainly: education (Tarbiyah), teaching (Ta'lim), refinement (Ta'dib) and urbanisation ('Imran).

\section{The concepts of education, teaching and refinement}

From scrutinising Ibn Khaldun's books, I have found that each of the three concepts of education, teaching and refinement has its own independent meaning.

\subsection{Education (Tarbiyah)}

Education has a broad meaning that encompasses man's - as an individual or group - bio-psychological, cognitive and ethical dimensions. It associates him progressively throughout his life; from birth until death, this meaning stated clearly by Ibn Khaldun's (1986, pp.371-372) then, an animal is destined for that human being. In that animal, an instinctive desire is created which is directed toward bringing that human being up (litarbiyatih) and being kind to him, until he [matures] fully and is weaned.

It is a complicated process that shapes man's personality and determines his attitude towards things. It is the socio-civilisational frame-work [Kelly, (1989), p.36], which is exemplified in the following story, narrated by Ibn Khaldun (1986, p.37): the wazir had been imprisoned by his ruler and remained in prison several years.

His son grew up in prison. When he reached the age of reason, he asked his father about the meat which he had been eating. His father told him that it was mutton, and he asked him what that was. When his father described a sheep to him in detail, the son said, father, you mean, it looks like a rat? His father was angry with him and said, what has a sheep to do with a rat? The same happened later about beef and camel meat. The only animals he had seen in prison were rats, and so he believed that all animals were of the same species as rats.

Prison in this story is a good example that represents the civilisational frame-work that possesses the main components that nourish and shape the boy's personality [Curtis, (1958), pp.36-37]. This meaning of education (tarbiyah) is in agreement with the root word (Rabb), Al-Fairuzabadi (1987, p.111) said: Rabb kull shay': malikuh, wamustahikkuh 'aw sahibuh which means ownership or the master of everything is its proprietor, beneficiary or holder.

Some other scholars limited the meaning of education focusing on its good aspects only by omitting bad behaviour and replacing it by good behaviour. Al-Ghazali (1986, p.120) stated that the meaning of education (tarbiyah) is like the deed of a farmer who pulls out prickles and parasite plants from the crops to fertilise them and make them grow properly. Ibn Khaldun (1986, p.305) on the other hand, education as a neutral framework that can be determined due to its contents thus, students, slaves, and servants who are 
brought up (marbah) with injustice and tyrannical force are overcome by it. It makes them lazy and induces them to lie and be insincere.

Functionally, the Khaldunic meaning of education corresponds, to some extent, with the contemporary concept of socialisation. Indeed, this meaning is embedded in the literal meaning of (tarbiyah). Al-'Asma'i said: rubawtu fi bani fulan 'arbu nasha'tu fihim, warababtu fulanan 'urabbi h tarbiyatan watarabbaytuh warabbabtuh warabbaytuh wa rabbabtuh bima'na wahid. Al-jawhari said: rabbabtuh tarbiyatan watarabbabtuh 'ay ghadhawtuh, qal: hakadha likul ma yunma kalwalad waalzar' wanahwih [Ibn Mandhur, (1990), p.307] which means to cultivate, socialise and bring up people and things. From this Khaldunic point of view, education represents the tool of socialisation this can be understood from his statement, it is better that such help be sought from persons close to the ruler through common descent, common upbringing (al-tarbiyah), or old attachment to the dynasty. This makes such persons and the ruler work together in the same spirit [Ibn Khaldun, (1986), pp.3-4]. Education also represents the aim as (al-Marzuqi) stated:

"education is the framework of all social activities: it is the aim." [Al-Marzuqui, (1983), p.67]

\subsection{Teaching}

According to Ibn Khaldun, teaching is a limited concept in its essence, occurrence and function:

- $\quad$ The essencential aspect: teaching is a natural phenomenon in human social organisation (al-'imran al-bashari) [Ibn Khaldun, (1986), p.411] science and teaching are natural in human social organisation (al-'imran al-bashari). Teaching attains this position for the following reasons:

1 As man, by nature, is driven to satisfy his biological needs through eating, drinking and sex- he is also driven naturally to satisfy his thinking needs through learning and gaining knowledge, in this respect Ibn Khaldun (1986, p.412) said: in connection with the ability to obtain the requirements of nature, which is engrained in man as well as, indeed, in animals, his ability to think [requires that he] obtain perceptions that it does not yet possess.

2 As this satisfaction cannot be obtained only through cooperation of man with his fellow because to Ibn Khaldun (1986, p.417) a single human being cannot live by himself, and his existence can materialise only in association with his fellow men.

(Alone) he would be unable to have a complete existence and lead a complete life. By his very nature, he needs the cooperation of others to satisfy all his needs. Therefore, teaching that satisfies fully his thinking needs cannot be accomplished except through a special cooperation, which doesn't appear except in urbanisation.

Teaching is also a craft, [Ibn Khaldun, (1986), p.426], scientific instruction is a craft.

According to him all crafts can be acquired only through habit he said: skill in science, knowledge of its diverse aspects, and mastery of it are the result of a habit which enables its possessor to comprehend all the basic principles of that particular science, to become acquainted with its problems, and to evolve the details of it from 
its principles. As long as such a habit has not been obtained, skill in a particular discipline is not forthcoming [Ibn Khaldun, (1986), p.426].

As a result, any craft needs famous teachers with regard to the instruction in any science or craft, [which] is acknowledged (to be necessary) by the people of every region and generation [Ibn Khaldun, (1986), p.426].

- The phenomenon aspect: teaching occurs later than education in time and space. As for the time aspect, teaching does not start with man from his first day of life as man is essentially ignorant, and becomes learned only through acquiring (knowledge) [Ibn Khaldun, (1986), p.425]. It is also not necessary that it continue with man until the end of his life and teaching as such can be done only by an intelligent and skilful man.

As from the space aspect, because teaching is a craft it does happen only in cities and people who grow up in villages and uncivilised (thinly populated) cities and who have an innate desire for scientific activity cannot find scientific instruction in those places. For scientific instruction is something technical, and there are no crafts among the inhabitants of the desert...these people, therefore, must travel and seek scientific instruction in cities where (civilisation) is highly developed (al-'amsar al-mustabh $\}$ arah), as is the case with the crafts [Ibn Khaldun, (1986), p.434].

- The functional aspect: According to Ibn Khaldun teaching and all other crafts -regardless of the type, whether it is a noble science or degrading, divine or evil- all such things are habits that add insight to the intellect of a man and [unique] enlightenment to his thinking [Ibn Khaldun, (1986), p.432]. Through teaching man reaches perfection of his form through knowledge, which he acquires through his own organs. Thus his human essence reaches the perfection of existence [Ibn Khaldun, (1986), p.434].

\subsection{Refinement}

Although refinement is less used in Ibn Khaldun's writing compared to education and teaching; it has its own essence and sphere.

\subsubsection{Essence}

Refinement means the formal custody and supervision; this meaning can be understood from his statement; the city, then, teems with low people of blameworthy character. They [such people] encounter competition from many members of the younger generation of the [local] dynasty, whose education (ta'dibahum) has been neglected and whom the dynasty has neglected to accept. They, therefore, adopt the qualities of their environment and company, even though they may be people of noble descent and ancestry [Ibn Khaldun, (1986), p.294].

This is a reference to experience and imitation in gaining proper habits and good practical manners with the meaning of the famous saying: (he who is not educated (yu'addibuh) by his parents will be educated ('addabah) by time that is, he who does not acquire the manners needed in dealing with human beings from his parents - which includes teachers and elders- and does not learn these things from them, has to fall back 
upon learning them with the help of nature from the events that happen in the course of time [Ibn Khaldun, (1986), p.412].

Additionally, it means the observance of certain courteous manners, [Ibn Khaldun, (1986), p.432] sedentary people observe (a) particular (code of) manners ('a dab) in everything they undertake and do or do not do, and they thus acquire certain ways ('a $\mathrm{dab}$ ) of making a living, finding dwellings, building houses, and handling their religious and worldly matters, including their customary affairs, their dealing with others, and the rest of their activities. These manners ('a dab) constitute a kind of limitation which may not be transgressed.

\subsubsection{Sphere}

Refinement - according to Ibn Khaldun's point of view- is limited only to good meanings that refer to proper habits and courteous manners. This limitation is in agreement with the literal meaning of ('adab) from which refinement (ta'dib) is derived.

Al-Zubaidi (1306H, p.144) said: breeding (al-'adab) is every praiseworthy training that conveys to man some virtues...that is, to say and do only what is praised, restricting oneself to expedient manners or respecting who is your senior and treating gently who is your junior.

These three concepts -education, teaching and refinement- can be summarised in Figure 1:

Figure 1 The diagram of similarities and differences between education, teaching and refinement

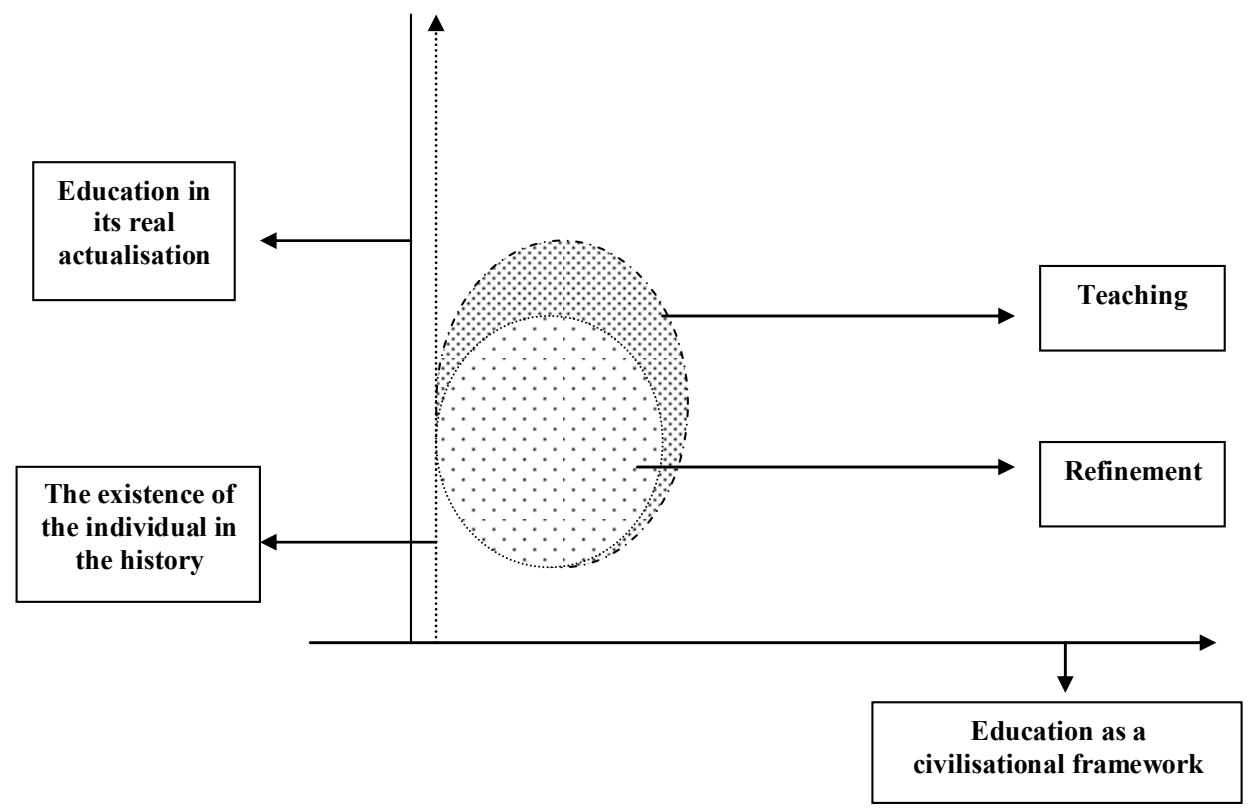

As it is shown in the diagram, education, on the one hand, represents functionally an actual process that starts with the existence of the individual in history and continues with him until his end. On the other hand, it represents symbolically the civilisational frame work that encompasses many factors, which contribute together in shaping man and 
society. Therefore its relation to teaching and refinement is an absolute general and particular relation. This means that every act of teaching or refinement is by nature a form of education, but not every form of education is teaching or refinement [Al-Mawsu'ah al- 'Arabiyah, (1996), p.198].

The diagram also indicates that the relation between teaching and refinement is an absolute general and particular relation if we disregard the insignificant contiguity in one of the two concepts' framework poles. This contiguity indicates a difference between the general and the particular. However, this discrepancy is a mere impermanent attribute which is not included in the definition of its subject; it was not a result of technical instruction (ta'lim sna 'i) or scientific education (ta'dib ta'limi) [Ibn Khaldun, (1986), p.260].

Consequently, we deduce that every refinement (ta'dib) is an act of teaching (ta'lim) and not every act of teaching is a refinement. Refinement, in short, can be included as a type of teaching which is specialised in fostering good manners and social habits as Ibn Khaldun, (1986, p.432) had stated: these manners ('a dab) constitute a kind of limitation which may not be transgressed, and, at the same time, they are crafts that (later) generations take over from the earlier ones. Therefore, our following illustration will be merely confined to education and teaching.

\subsubsection{The social function of education}

Education has two social functions; the first one, as a civilisational framework, and the second one, in its real actualisation:

1 The first social function is that education represents the worldview of the nation. It is its framework, which precedes and delineates all its societal institutions; because accourding to Ibn Khaldun (1986, p.305) religion and religious organisation ('al-din wa al-millah) constitute the form of existence and royal authority, which (together) constitute the matter for (religion). Form is prior to matter.

2 The second social function is like what it is called nowadays socialisation [Dewey, (1916), p.13] which means to manipulate man and make him adopt and act upon his society's norms; as it is clearly stated by Ibn Khaldun (1986, p.258) the fact that man is a child of the customs and the things he has become used to. He is not the product of his natural disposition and temperament. The conditions, to which he has become accustomed, until they have become for him a quality of character and matters of habit and custom, have replaced his natural disposition. If one studies this in human beings, one will find much of it, and it will be found to be a correct (observation).

From the Khaldunic point of view, because not everyone is master of his own affairs, education from this aspect is controlled and derived in every society by the influential people who have authority and power, Ibn Khaldun (1986, p.258), not everyone is master of his own affairs. Chiefs and leaders who are masters of the affairs of men are few in comparison with the rest. As a rule, man must by necessity be dominated by someone else. Moreover, Ibn Khaldun sees no difference between the socialisation that is done by the rulers or by the educators, both of them endeavour to manipulate man and cultivate him in line with the society's rules and customs; Ibn Khaldun (1986, p.258), governmental and educational laws influence sedentary people, in that they weaken their souls and diminish their stamina, because they have to suffer (their authority) both as 
children and as adults. Hence, man's personality differs due to the sort of authority that dominates him, which is of three types; kind (rafiqah), brutal (qahirah) and punitive ('iqabiyah):

1 Kind authority yields a man who is self-reliant, courageous, sincere and free from all social hypocrisy; if the domination is kind and just and the people under it are not oppressed by its laws and restrictions, they are guided by the courage or cowardice that they possess in themselves. They are satisfied with the absence of any restraining power. Self reliance eventually becomes a quality natural to them. They would not know anything else [Ibn Khaldun, (1986), pp.258-259].

This type of domination depends in its socialisation to develop in people critical thinking and a self-restraining influence; when the Muslims got their religion from thelawgiver (Muhammad), the restraining influence came from themselves as a result of the encouragement he gave them in the Qur'an [Ibn Khaldun, (1986), p.260].

2 Brutal authority, on the other hand, creates a subservient, indolent, deceitful and irresponsible man; [Ibn Khaldun, (1986), p.259] if, however, the domination with its laws is one of brute force and intimidation, it breaks their fortitude and deprives them of their power of resistance as a result of an inertness that develops in the souls of the oppressed.

3 Punitive authority destroys people completely and generates humiliation in them; [Ibn Khaldun, (1986), p.259] when laws are (enforced) by means of punishment, they completely destroy fortitude, because the use of punishment against someone who cannot defend himself generates in that person a feeling of humiliation that, without doubt, will break his fortitude. No matter whether this punishment is carried out by politicians or by educators it leads to the same result which is the dehumanisation of man especially if it started with him from his childhood; [Ibn, Khaldun, (1986), p.259], when laws are (intended to serve the purpose of) education and instruction and applied from childhood on, they have, to some degree, the same effect, because people then grow up in fear and docility and consequently do not rely on their own fortitude.

\subsubsection{The social function of teaching}

The social function of teaching can be divided into the three following general categories:

1 Teaching people different kinds of crafts and various sorts of businesses, so that they might be able to make a living and earn their sustenance [Ibn Khaldun (1986), p.29].

2 Recording experiences and knowledge through teaching the noble craft (writing) because writing is the main tool that enables people to become acquainted with science, learning with the books of the ancients, and with the sciences and information written down by them. Because of all these useful aspects, (writing) is noble. The transformation of writing in man from potentiality into actuality takes place through instruction [Ibn Khaldun, (1986), pp.377-378].

3 The most important social function of teaching is to develop and enhance man's humanity; Ibn Khaldun (1986, p.425) in his first condition, before he has attained discernment, man is simply matter, in as much as he is ignorant of all knowledge. He 
reaches the perfection of his form through knowledge, which he acquires through his own organs. Thus, his human essence reaches the perfection of existence, because knowledge represents for the man's soul and mind what nourishment represents for the body. As food and drink are essential for man's biological facets [as nourishment], knowledge and its [application] are, also, necessary for man's incorporeal dimension to develop and reach its completeness [Ibn Khaldun, (1996), p.57].

\section{The civilisational progress and its impact on the sciences}

According to Ibn Khaldun, there is a causal relationship between civilisational progress and the sciences. This means that the greater urbananisation ('imran) is and the more highly developed its civilisation becomes the more the sciences develop and advance and vice versa; Ibn Khaldun (1986, p.434), the sciences are numerous only where civilisation (hadarah) is large and sedentary culture ('imran) is highly developed. But before we go into more detail we need to illustrate the following related concepts:

1 Necessary (al-daruri): it is essential in the existence of its things; Ibn Khaldun (1986, p.91) social organisation is necessary to the human species.

Without it, the existence of human beings would be incomplete. It also means the root of things; Ibn Khaldun (1986, p.252) necessities, in a way, are basic.

2 Convenience (al-hajji): it is not essential but it is needed to diminish difficulty and inconvenience [Al-Shatibi, (nd), pp.4-5].

3 Luxury (al-kamali): it goes beyond convenience to the point of self indulgence; man first seeks the (bare) necessities. Only after he has obtained the (bare) necessities, does he get comforts and luxuries [Ibn Khaldun, (1986), p.252].

Although Ibn Khaldun had mentioned convenience as a counterpart to necessity and luxury in many places such as social organisation enables them to cooperate toward that end to start with the simple necessities of life, before they get to the conveniences and luxuries [Ibn Khaldun, (1986), p.249], and they do not possess conveniences and luxuries beyond these bare necessities. He functionally, reduced it sometimes to necessity; only after he has obtained the (bare) necessities, does he get to comforts and luxuries [Ibn Khaldun, (1986), p.252].

And at some other times he reduced it to luxury [Ibn Khaldun, (1986), p.252] the bare necessities, are no doubt prior to the conveniences and luxuries. (Bare) necessities, in a way, are basic, and luxuries secondary and an outgrowth (of the necessities).

It seems that Ibn Khaldun considered convenience as a crossing point between necessity and luxury. Its classification depends on habits ('adah); if the habit inclined towards necessity, convenience will be more similar to luxury; [Ibn Khaldun, (1986), p.253], sedentary people, on the other hand, have no desire for desert conditions, unless they are motivated by some urgent necessity or they cannot keep up with their fellow city dwellers. On the other hand, if the habit is inclined to 
luxury then convenience will be more akin to the necessity; Ibn Khaldun (1986, p.279) "the needs (hajat) of the inhabitants increase on account of luxury".

4 Urbanisation ( 'imran): according to Ibn Khaldun, urbanisation means gathering and cooperation. He said: (al-'imran) means that human beings have to dwell in common and settle together in cities and hamlets for the comfort of companionship and for the satisfaction of human needs, as a result of the natural disposition of human beings towards cooperation in order to be able to make a living [Ibn Khaldun, (1986), p.84].

Urbanisation is of two types: rural (badawi) and sedentary (hadari); Ibn Khaldun (1986, pp.84-85) (al-'imran) may be either desert (Bedouin) ('imran) as found in the outlying regions and mountains, in hamlets (near suitable) pastures in waste regions, and on the fringes of sandy deserts. Or it may be sedentary ('imran) as found in cities, villages, towns, and small communities. Urbanisation ( imran) whether rural or sedentary is necessary to humankinds; Ibn Khaldun (1986, p.91) social organisation is necessary to the human species. Without it, the existence of human beings would be incomplete. God's desire to settle the world with human beings and to leave them as His representatives on earth would not materialise on earth.

Urbanisation ('imran) is a necessity from which all other necessities are generated. It is the main factor of man's creativity and progression in this world. It is the zero degree in man's humanity parameter scale; if we start from the zero degree climbing up the scale man's humanity is actualised and enhanced. On the other hand, if we start from the zero degree going down the scale; man's humanity is gradually contracts and becomes closer to animality and the savage state.

Figure 2 Man's humanity parameters

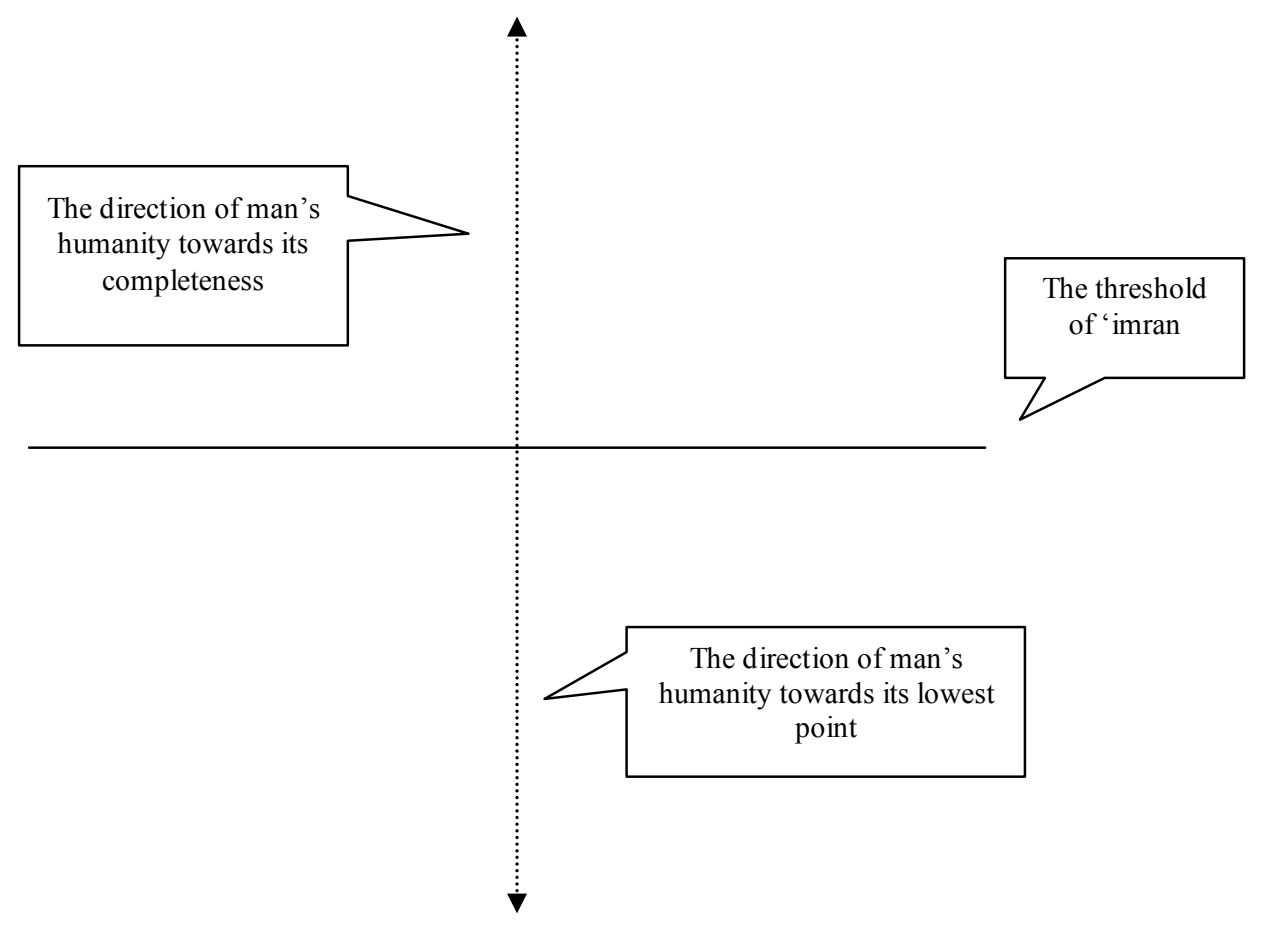


Ibn Khaldun categorises the necessities that are generated by Urbanisation ( imran) into the following four classes: the first and second necessities are nourishment and selfdefense. He said: As long as there is no such cooperation, he cannot obtain any food or nourishment, and life cannot materialise for him, because God fashioned him so that he must have food if he is to live. Nor, lacking weapons, can he defend himself. Thus, he falls prey to animals and dies much before his time. Under such circumstances, the human species would vanish [Ibn Khaldun, (1986), pp.90-91].

The third necessity is shelter; Ibn Khaldun (1986, p.257), it is unavoidable that he must reflect upon how to avert the harms arising from heat and cold by using houses. The fourth necessity is royal authority (al-mulk); Ibn Khaldun (1986, pp.91-92) people need someone to exercise a restraining influence on them and keep them apart, for aggressiveness and injustice are in the animal nature of man...it has thus become clear that royal authority is a natural quality of man which is absolutely necessary to mankind.

The first three necessities are the root of crafts which are the main substance and field of teaching [Ibn Khaldun (1986), p.351], if a particular craft is in demand and there are buyers for it, (that) craft then corresponds to a type of goods that is in great demand and imported for sale. People in the towns, therefore, are eager to learn (that particular) craft, in order to make a living through it. The fourth necessity, on the other hand, is the main necessity that dominates crafts and determines the value of each of them; Ibn Khaldun (1986, p.351), it is the ruling dynasty that demands crafts and their improvement. It causes the demand for them and makes them desirable...the dynasty is the biggest market. There, everything can be marketed. It does not make any difference whether it is little or much. Whatever is in demand with the dynasty is by necessity, a major article.

5 Civilisation (Hadarah): civilisation is [Ibn Khaldun, (1986), p.292] the adoption of diversified luxuries (al-taraf), the cultivation of the things that go with them, and addiction to the crafts that give elegance to all the various kinds of (luxury). It varies in its strength and spread; Ibn Khaldun (1986, p.351), sedentary culture (Hadarah) differs according to the differences in (al-'imran). When (al-'imran) grows, sedentary culture (al-hadarah) becomes more perfect [Ibn Khaldun, (1986), p.292]. It is also the aim of urbanisation (al-'imran) and the indicator of its ruin, Ibn Khaldun (1986, p.291) sedentary culture (al-hadarah) is the goal of (al-'imran). It means the end of its life span and brings about its corruption. However, the corruption and end of urbanisation do not also mean the corruption and end of civilisation (al-hadarah). Because it has the ability of reformation and transmission from one generation to the other, Ibn Khaldun (1986, p.351) sedentary culture (al-hadarah) was always transferred from the preceding dynasty to the later one.

The sedentary culture (al-hadarah) of the Persians was transferred to the Arab Umayyads and 'Abbasids...the larger a dynasty, the more important is its sedentary culture. For sedentary culture is the consequence of luxury. Based on these five concepts; we can summarise the progress of urbanisation and its impact on teaching development in the following diagram: 
Figure 3 The scale of the progress of urbanisation and its impact on the development of teaching

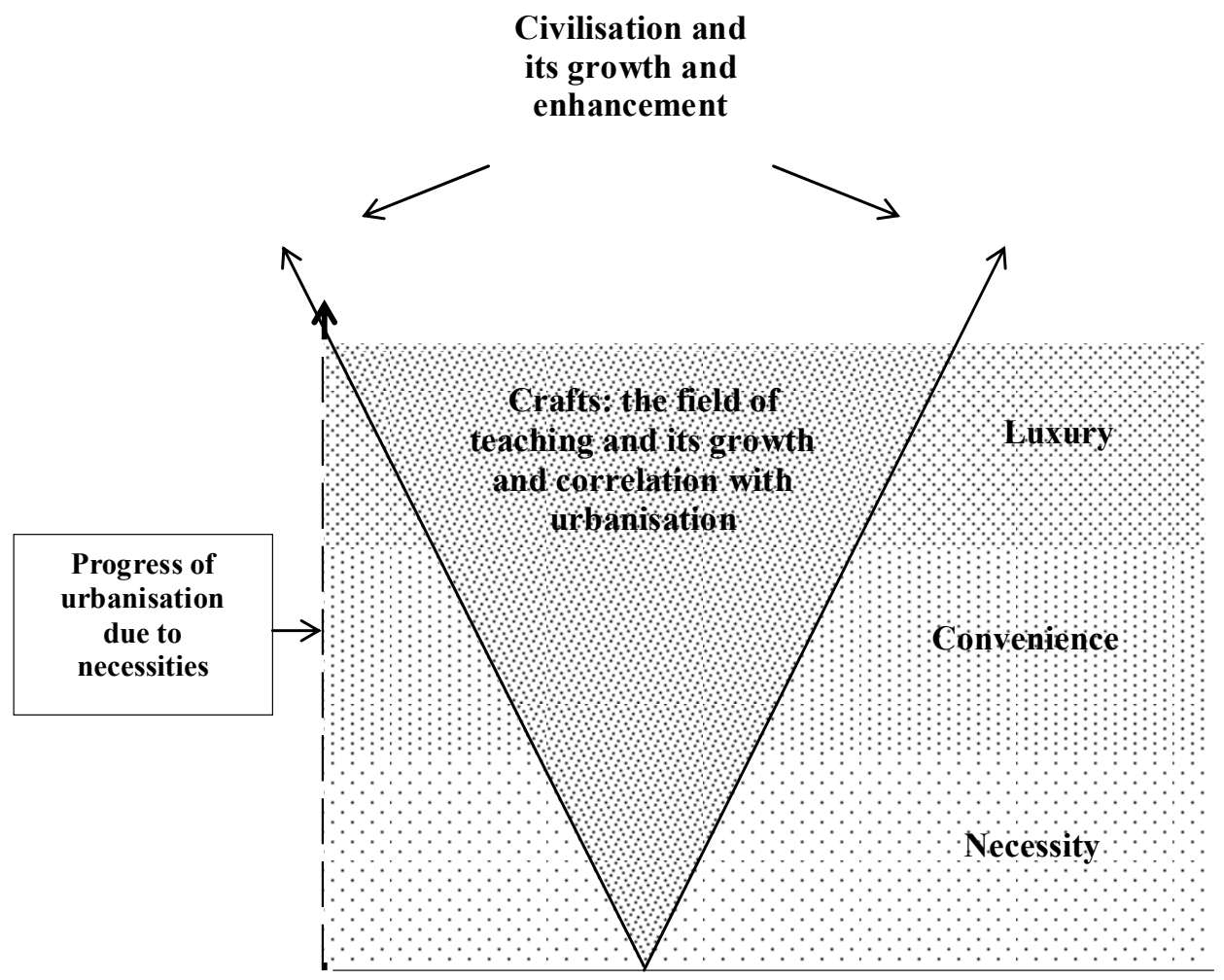

As it is shown in this diagram, there is a correlation between the development of urbanisation and the progress of teaching; the greater the development of urbanisation and civilisation, the more crafts and their teaching evolve; Ibn Khaldun (1986, p.349) "the crafts are firmly rooted in a city ('amsa r) when sedentary culture (alhadarah) is rooted and for a long duration. This is the equation in its briefest form, but in reality, it is a complicated network of cause-effect relations that is difficult to decode. Therefore, we will confine ourselves to those which can help us to have a better understanding."

We have seen that civilisation is the adoption of diversified lavishness, and an addiction to the crafts that give elegance to all its various expressions. We know also that lavishness (al-taraf) happens under the category of luxuries (al-kamaliyat) section, which comes after necessity is achieved; [Ibn Khaldun, (1986), p.272] the combined labour produces more than the needs and necessities of the workers.

If the labour of the inhabitants of a town or city is distributed in accordance with the necessities and needs of those inhabitants, a minimum of that labour will suffice. The labour (available) is more than is needed. Consequently, it is spent to provide the conditions and customs of luxury.

The development of crafts - the substance of teaching- and its boom is correlated with supply and demand [Ibn Khaldun, (1986), p.351] crafts can improve and increase only when many people demand them. Because craft represents the source of profit and livelihood of its owner, he will then be eager to learn what is demanded in the market. As 
a result, the demanded craft will flourish and vice versa; [Ibn Khaldun, (1986), p.351] if a particular craft is in demand and there are buyers for it, that craft, then, corresponds to a type of goods that is in great demand and imported for sale. People in the towns therefore, are eager to learn (that particular) craft, in order to make a living through it. On the other hand, if a particular craft is not in demand, there are no buyers for it, and no one is interested in learning it. As a result, the craft is destined to be left alone and disappears because of neglect. But the entity which controls the market and makes crafts which are in great demand by the consumers is the government, which according to Ibn Khaldun, (1986, p.352) demands crafts and their improvement. It causes the demand for them and makes them desirable. The more urbanisation is distended, the more the surplus value is magnified, consequently people's incomes will be greater than their needs then their incomes will be spent on lavishness. In turn, crafts will flourish [Ibn Khaldun, (1986), pp.372-373] when (al-'imran) increases, and the (available) labour again increases. In turn, luxury (al-taraf) again increases in line with the increasing profit, and as needs for luxury (al-taraf) increase. Crafts are created to obtain (luxury products). The value realised from the increases, and, as a result, profits are again multiplied in the town.

Production there is thriving even more than before. And so it goes with the second and third increase. All the additional labour serves luxury (al-taraf) and wealth. The perfection, expansion and variation of crafts depend on the size and type of urbanisation. The more urbanisation grows and expands the more crafts vary and improve and vice versa; [Ibn Khaldun, (1986), pp.347-348] the susceptibility of the crafts to refinement, and the quality of the purposes they are to serve in view of the demands made by luxury and wealth, correspond to the ('imran) of a given country. A small or Bedouin ('imran) needs only simple crafts, especially those used for necessities...they exist there. Still, they are neither perfect nor well-developed.... when ('imran) flourishes and luxuries are in demand, it includes the refinement (ta'annuq) and development of the crafts.

On the other hand, the expansion of urbanisation ('imran) depends on the vigorous increase of procreation, and the increase of procreation itself depends on the rise in productivity and profit, and the rise in productivity and profit are themselves subjected to people's psychological security, and the latter is allied to the kindness and benevolence of the ruler; [Ibn Khaldun, (1986), p.300] a kind and benevolent ruler serves as an incentive to the subjects and gives them energy for cultural activities. (al-'imran) willbe abundant, and procreation will be vigorous. In contrast, if the ruler is a tyrant, peoplewill be lazy and apathetic to working because they have lost [Ibn Khaldun, (1986), p.103] the incentive to acquire and own property. Consequently, the market and crafts will be stagnant, and due to that the procreation will decrease and urbanisation (al-'imran) will disintegrate. In turn, [Ibn Khaldun, (1986), p.104] the disintegration of (al-'imran) causes the disintegration of the status of the dynasty and the ruler, because (their peculiar status) constitutes the form of (al-'imran) and the form necessarily decays when its matter (in this case, al-'imran) decays, because, according to Ibn Khaldun (1986, p.135) one cannot imagine a dynasty without a ('imran), while a (al-'imran) without a dynasty and royal authority is impossible.

\section{Conclusions}

Through the presentation of the concepts of education, teaching and refinement and their correlation with civilisation and human urbanisation, rigorous thought of Ibn Khaldūn 
and its objectivity became clearly evident. It became clear that every concept has its intellectual sense and realistic limitations; each concept functions according to its role and task in its social and cultural contexts. According to Ibn Khaldūn, education on the one hand represents a general cultural framework, governing the movement of the society and its process of becoming a civilisation; and on the other hand, it represents effective community tools in building the individual and his social growth from his birth to the last moment of his life, it is an ongoing process and an inexhaustible, and unceasing flowing river.

It differs in its results depending on the quality of supervising authorities of its manifestations and real actualisations, it can either be a tool of development and progress for the individual and realisation of his humanity and the development of his potentials and talents; or it can be a tool of domestication of the individual and distortion of his humanity and the paralysation of its energy and potential.

Teaching is the incidental industrial process in the life of the individual with specific objectives which is illustrated in the transfer of knowledge, sciences and crafts, and developing the intellectual and practical skills in order to ensure his existential being, boost his human status and enhance his social status. The quality of teaching and its differentiations are connected accordingly to the development of industries that in turn are linked to the size and density of civic population and its expansion and the depth of the civilisation and his durability.

The refinement is an artificial process which is complementary to teaching. It is concerned with edifying the individual and providing him the civic morals and customs. by selecting these concepts and stating their overlaps and interactions, Ibn Khaldūn guides us to the ways of real awakening. These ways are:

1 clear and appropriate educational philosophy; and a responsible, caring political and educational authority which respects the humanity of the individual and appreciates his position

2 an instructional curriculum with clearly defined objectives which helps the individual in developing his capabilities and talents

3 the inoculation of the curriculum with civic morals and its highest ideals.

This is a general idea about the concepts of education, teaching and refinement and their correlation with urbanisation ('imran) and its components, which collectively, represent some of the tools of Ibn Khaldun's philosophy of reformation. I hope that it will help to whet the appetite of its readers for further research in what I believe is a new dimension of the Khaldunic philosophy of reformation.

\section{References}

Al-fairuzabadi, majd al-din Muhammad bin Ya'qub (1987) Qamus al-Muhit, 3rd ed., mu'assasat al-Risalah, Bairut.

Al-Ghazali, abu Hamid muhammad bin Muhammad (1986) 'Ayyuha al-Walad', Matlub, A. (Ed.): Matba'ah Wizarah al-'Awqaf wa al-Shu'un al-Diniyyah, Iraq.

Al-Marzuqui abu Ya'rib (1983) Al-'Ijtima' al-Nadhari al-Khulduni wa al-Tarikhal-'Arabi alMu'asr, al- Dar al-'Arabiyah li-alkitab, Bairut.

Al-mawsu'ah al-'Alamiyah (1996) Al-Riyaz: Mu'assasah 'Amal al-Mawsu'ah li-Alnashir wa al-Tawzi'. 
Al-Shatibi, abu 'Ishaq 'Ibrahim bin Musa (no date) Al-Muwafaqat fi 'Usul al-'Ahkam, Dar al-Fikir, no place.

Al-Zubaidi, al-Saiyid Muhammad Murtaza (1306H) Taj al-'Arus, Masir: al-Matba'ah al-Khairiyah.

Curtis, S.J. (1958) An Introduction to the Philosophy of Education, University Tutorial Press LTD, London.

Dewey, J. (1916) Democracy and Education, an Introduction to the Philosophy of Education, The Macmillan Company, New York.

Ibin Mandhur, Jamal al_Din Muhmamad bin Mukrim (1990) Lisan al-'arab, Bairut: Dar Sadir.

Ibn Khaldun (1986) The Muqaddimah, Trans. Franz Rosenthal, Routledge and Kegan Paul, London and Henley.

Ibn Khaldun, Abid al-Rahman bin Muhammad (1996) Shifa' al-Sa'il wa tahthib al-Masa'il, dar al-Fikir al-Mu'asr, Bairut.

Kelly, A.V. (1989) The Curriculum Theory and Practice, 3rd ed., Paul Chapman Publishing Ltd., London. 